\title{
Maltose Production Using Starch from Cassava Bagasse Catalyzed by Cross-Linked $\beta$-Amylase Aggregates
}

\author{
Rafael Araujo-Silva ${ }^{1}$, Agnes Cristina Oliveira Mafra ${ }^{1,+}{ }^{+}$, Mayerlenis Jimenez Rojas ${ }^{1}$, \\ Willian Kopp ${ }^{2}$, Roberto de Campos Giordano ${ }^{1}$, Roberto Fernandez-Lafuente ${ }^{3, *}$ (i) and \\ Paulo Waldir Tardioli $1, *$ (iD \\ 1 Graduate Program in Chemical Engineering, Department of Chemical Engineering, Federal University of \\ São Carlos, Rod. Washington Luiz, São Carlos 13565-905, Brazil; rafa.araujo.silva@outlook.com (R.A.-S.); \\ agnesmafra@ufmt.br (A.C.O.M.); mayerlenis@gmail.com (M.J.R.); roberto@ufscar.br (R.d.C.G.) \\ 2 Kopp Technologies, Rua Alfredo Lopes, 1717, São Carlos 13560-460, Brazil; willkopp@gmail.com \\ 3 Departamento de Biocatálisis, ICP-CSIC, Campus UAM-CSIC Madrid, Madrid 28049, Spain \\ * $\quad$ Correspondence: rfl@icp.csic.es (R.F.-L.); pwtardioli@ufscar.br (P.W.T.); Tel.:+34-915954941 (R.F.-L.); \\ +55-16-3351-9362 (P.W.T.) \\ + Present address: Instituto de Engenharia de Várzea Grande, Universidade Federal de Mato Grosso, \\ Av. Fernando Corrêa da Costa, 2367, Cuiabá 78060-900, Brazil.
}

Received: 20 March 2018; Accepted: 19 April 2018; Published: 21 April 2018

\begin{abstract}
Barley $\beta$-amylase was immobilized using different techniques. The highest global yield was obtained using the cross-linked enzyme aggregates (CLEA) technique, employing bovine serum albumin (BSA) or soy protein isolate (SPI) as feeder proteins to reduce diffusion problems. The CLEAs produced using BSA or SPI showed $82.7 \pm 5.8$ and $53.3 \pm 2.4 \%$ global yield, respectively, and a stabilization effect was observed upon immobilization at neutral $\mathrm{pH}$ value, e.g., after $12 \mathrm{~h}$ at $55^{\circ} \mathrm{C}$, the free $\beta$-amylase is fully inactivated, while CLEAs retained 25 and $15 \%$ of activity (using BSA and SPI, respectively). CLEA using SPI was selected because of its easier recovery, being chosen to convert the residual starch contained in cassava bagasse into maltose. This biocatalyst permitted to reach almost $70 \%$ of maltose conversion in $4 \mathrm{~h}$ using $30.0 \mathrm{~g} / \mathrm{L}$ bagasse starch solution (Dextrose Equivalent of 15.88) and $1.2 \mathrm{U}$ of biocatalyst per gram of starch at $\mathrm{pH} 7.0$ and $40{ }^{\circ} \mathrm{C}$. After 4 reuses (batches of $12 \mathrm{~h}$ ) the CLEA using SPI maintained $25.50 \pm 0.01 \%$ of conversion due to the difficulty of recovering.
\end{abstract}

Keywords: barley $\beta$-amylase; cross-linked enzyme aggregates (CLEA); cofeeders; enzyme immobilization; cassava bagasse

\section{Introduction}

Cassava (Manihot esculenta Cranz) is produced worldwide and plays an important role in food security in tropical areas [1]. One of the most important cassava industrial products is starch [2], which is usually extracted by a mechanical shear. The mechanical extraction of starch from 1 ton of cassava roots results in $254.7 \mathrm{~kg}$ of starch ( 10\% moisture) and $928.6 \mathrm{~kg}$ bagasse (85\% moisture) [3]. Sriroth et al. [4] reported that the mechanical extraction of starch from cassava is limited, removing only partially the starch existing in the root fibers. The bagasse waste can contain up to $60 \mathrm{wt} \%$ of starch (dried basis) and is usually considered as a residue and disposed to the environment as landfill without any treatment [2], although in some instances it is used in animal feed mixtures or as additive to enrich fertilizers [2,4,5]. An alternative application of the residual starch from cassava waste could be the conversion into added-value products such as maltodextrins, glucose and maltose 
syrups using amylolytic enzymes. Maltose is widely used in the food industry, particularly in the brewing industry [6].

The starch chain can be hydrolyzed into dextrins by several groups of amylases [7,8]. $\alpha$-Amylases cleave the starch molecule into smaller oligosaccharides, being used to improve the gelatinization process, in enzymatic starch extraction, to decrease medium viscosity and in saccharification processes (combined or not with other amylases) [7,8]; $\beta$-amylases (EC 3.2.1.2) are responsible for partial hydrolysis of starch non-reducing ends into maltose molecules [7-9]. There are several different sources of $\beta$-amylase, i.e., Bacillus spp, Bacillus cereus, soybean, sweet potato and barley $[7,8]$. A commercial $\beta$-amylase used for maltose production is that from barley [7]. Barley $\beta$-amylase has a monomeric structure with a molecular mass of 56-60 $\mathrm{kDa}$ [10], high activity in a $\mathrm{pH}$ ranging from 4.0 to 7.0 (optimum $\mathrm{pH}$ of 4.35 [11]). However, it is unstable at temperatures over $55^{\circ} \mathrm{C}[12,13]$. The use of a high temperature is desirable in maltose syrup production to improve operational aspects like viscosity of gelatinized starch solutions and highly concentrated sugar solutions and to avoid microbial growth [7]. Moreover, it looks convenient for the economy of the process to develop strategies that may permit the easy reuse of the barley $\beta$-amylase in several reactions cycles.

The enzyme immobilization may be a solution for these enzyme problems and even other enzyme limitations [14-17]: it allows a simple biocatalysts recovery and reuse [18], and becomes a powerful tool to improve enzyme features [19,20], such as stability [21,22], selectivity, specificity [23] or even purity [24]. These advantages have, as main costs, the immobilization process and immobilization carrier prices.

Chitosan is a prominent and versatile support, allowing different immobilization strategies [25-28]. It is obtained by deacetylation of chitin, a component of the exoskeleton of crustaceans and other arthropods [26]. That way, a support containing primary amino groups is easily obtained from a residue. This support may be used to directly ionically exchange enzymes [29], enabling a reversible immobilization that may not have high stabilizing effects on the protein [30]. The reversibility of the immobilization enables the reuse of the support, but may also raise a problem: the release of the enzyme during operation. To solve this, covalent glutaraldehyde immobilization may be a good alternative, this is a very used reactive even though the exact mechanism is unknown [31-33]. Amino-glutaraldehyde supports are heterofunctional ones [34] and they are very versatile for enzyme immobilization [35], enabling the use of glutaraldehyde preactivated supports [36] or the treatment of the previously adsorbed enzymes to obtain enzyme-support bonds [37]. Recently, the effect of the $\mathrm{pH}$ on the first immobilization step has been also showed $[38,39]$. Chitosan may be also utilized to encapsulate the enzyme $[40,41]$. Encapsulation has always the risks of enzyme release, as the pores need to be very small to relay trap the enzyme [42-44], but using chitosan some ion exchange of the enzyme on the polymer may be expected to reduce the enzyme release and crosslinking with glutaraldehyde may further reduce this enzyme leakage.

Professor Sheldon's group proposed a strategy that avoided the use of supports to immobilize enzymes: the cross-linked enzyme aggregates (CLEAs) [45-47]. The preparation of CLEAs is a very simple method that consists of two steps: (i) aggregation/precipitation of proteins induced by precipitant agents (salts, water-miscible organic solvents, non-ionic polymers, etc.); and (ii) chemical crosslinking of the formed aggregates with a bifunctional reagent (e.g., glutaraldehyde) via reaction with amino groups of the lysine residues that are presented on the surface of the enzyme $[48,49]$. However, if the enzyme has low surface density of amino groups, the immobilization could be inefficient, due to the low cross-linking bonds. Some authors suggest the amination of the enzyme (genetically or chemically) [50,51], or the coaggregation of enzyme and aminated polymers [52,53]. Yet, the first solution is complex and the second one produces a highly hydrophilic and cationic micro-environment around the enzyme that may be undesired. An alternative with a great success is the use of a feeder protein rich in lysine residues, such as bovine serum albumin (BSA), which can contribute to the formation of CLEAs with high global yield and excellent operational stability [48,49,54-60]. A cheaper alternative to BSA is soy protein isolate (SPI). This is an industrial 
residue from extraction of soybean oil [61], which has about $90 \%$ of heterogenic protein content, mainly composed by 7S ( $\beta$-conglycinin) and 11S (glycinin) storage proteins [62], of molecular sizes of 150-175 kDa [63] and 340-375 kDa [64], respectively. SPI is about 250 times cheaper than BSA ( $\mathrm{R} \$ 34.90 / \mathrm{kg}$ and $\mathrm{R} \$ 9803.00 / \mathrm{kg}$, respectively; values from Estação dos Grãos Ltd. (Perdizes, Brazil) and Sigma-Aldrich (St. Louis, MO, USA) in March 2018), what could turn CLEA technology economically viable when a feeder protein is necessary. The feeder could also reduce other CLEAs problems, due to the high volumetric activity in many instances diffusion limitations become very high and the feeder protein will "dilute" the enzyme [18].

Several researchers immobilized $\beta$-amylases from different sources using carrier-bound methods, stabilizing the enzyme [65-67] but recovering low activity [65-69], attributed mainly to substrate diffusional problems. As far as we know, there are no reports about the immobilization of $\beta$-amylase by the CLEA technique.

This study shows an option for the use of cassava bagasse as starch source for maltose production and explores the barley $\beta$-amylase immobilization by different techniques, including the CLEA methodology using two different feeder proteins, bovine serum albumin (BSA), which is used as feeder protein in many other studies [48,54-60], and soy protein isolate (SPI). The best biocatalyst obtained in this study will be tested in the maltose production using commercial and residual cassava starch.

\section{Results and Discussion}

\section{1. $\beta$-Amylase Immobilization}

The enzyme was first immobilized using chitosan as a carrier using the different strategies described in the Methods section. Immobilization via ion exchange presented low immobilization and global yields (less than 25\%, Table 1); however, high expressed activity was achieved (around $100 \%$ ). The treatment of the already ionically exchanged enzyme with glutaraldehyde drives to full enzyme inactivation. Immobilization on glutaraldehyde activated chitosan permitted the full enzyme immobilization, but the expressed activity and global yield were very low (just over $6 \%$ ). Thus, these strategies seem unsuitable to immobilize this enzyme; as an alternative, we tried to trap the enzyme on chitosan beads at a lower concentration, to have larger pores. The immobilization is not really a trapping, as the polymer will ionically immobilize the enzyme and we treat the immobilized enzyme with glutaraldehyde; in any case the expressed activity was even lower than in the other cases, perhaps the enzyme may be released, perhaps the polymer may block the active center of the enzyme, or the glutaraldehyde inactive the enzyme.

Table 1. Carrier-bond immobilization using chitosan $2 \%$ (for adsorption and covalent attachment), $1 \%$ (for encapsulation) and free-carrier immobilization (CLEA) without feeder protein. It was supplied $0.53 \mathrm{mg}$ of protein per gram of carrier in each immobilization method using chitosan.

\begin{tabular}{cccc}
\hline Immobilization Method & Immobilization Yield (\%) & Expressed Activity (\%) & Global Yield (\%) \\
\hline Adsorption & $21.4 \pm 3.4$ & $108.9 \pm 17.6$ & $23.3 \pm 3.8$ \\
Adsorption followed by crosslinking $^{1}$ & $21.4 \pm 3.4$ & $0.0 \pm 0.0$ & $0.0 \pm 0.0$ \\
Covalent attachment $^{2}$ & $100.0 \pm 0.0$ & $6.7 \pm 0.8$ & $6.7 \pm 0.8$ \\
Encapsulation $^{3}$ & - & - & $1.1 \pm 0.5$ \\
CLEA $^{4}$ & - & - & $34.2 \pm 3.3$ \\
CLEA $^{5}$ & - & - & $25.8 \pm 1.2$ \\
\hline
\end{tabular}

${ }^{1}$ Using $0.15 \%$ glutaraldehyde solution as crosslinker; ${ }^{2}$ activated with $0.80 \%$ glutaraldehyde solution; ${ }^{3}$ using $0.10 \%$ glutaraldehyde solution as crosslinker; ${ }^{4}$ using $0.30 \%$ glutaraldehyde solution as crosslinker; ${ }^{5}$ using $0.60 \%$ glutaraldehyde solution as crosslinker.

For this reason we tried the immobilization of $\beta$-amylase using CLEA technology. The results (Table 1) were better than when using chitosan (near to $30 \%$ of global yield). Thus, CLEAs technology appeared to be more suitable to immobilize this $\beta$-amylase, with the advantage of saving the support. 
Aiming to improve the CLEA global yield, we tried to optimize some immobilization aspects of this biocatalyst.

\subsection{Optimization of $\beta$-Amylase Immobilization Using CLEAs Technology}

To optimize the CLEA, we decided to use feeder proteins. As explained in introduction, this may have a double positive effect: to improve the crosslinking step and to reduce the diffusion problems by diluting the enzyme into inert protein $[46,48,49]$. Thus, the effects of the feeder proteins (BSA or SPI) and glutaraldehyde concentrations for the same $\beta$-amylase concentration on the global yield were studied (Section 3.4). More than $80 \%$ of global yield was achieved using BSA as feeder at condition 5 (CLEA- $\beta$-BSA-5) and more than 50\% using SPI as feeder at condition 12 (CLEA- $\beta$-SPI-12), as presented in Table 2. Using a feeder protein, the final activity of the biocatalyst was higher than using just the enzyme.

Table 2. Global yields for CLEAs of $\beta$-amylase prepared with different concentrations of feeder protein and glutaraldehyde.

\begin{tabular}{ccc}
\hline Assay & Feeder Protein & Global Yield (\%) \\
\hline 1 & None & $34.2 \pm 3.3$ \\
2 & & $25.8 \pm 1.2$ \\
\hline 3 & & $54.5 \pm 0.9$ \\
4 & & $43.2 \pm 0.4$ \\
5 & BSA & $82.7 \pm 5.8$ \\
6 & & $53.1 \pm 0.1$ \\
7 & & $33.6 \pm 0.5$ \\
8 & & 0 \\
9 & & 0 \\
10 & & 0 \\
11 & & $45.2 \pm 2.1$ \\
12 & & $53.3 \pm 2.4$ \\
13 & & $48.0 \pm 2.3$ \\
14 & & $47.5 \pm 1.5$ \\
15 & & $38.2 \pm 5.2$ \\
16 & & $31.0 \pm 1.8$ \\
18 & & $28.4 \pm 2.9$ \\
19 & & $24.4 \pm 0.5$ \\
\hline
\end{tabular}

The CLEAs obtained using SPI (CLEA- $\beta$-SPI) were noticeably larger than the CLEAs produced using BSA or without feeder protein, helping in the separation of the biocatalyst from the viscous medium when submitted to centrifugation. This larger size may be the cause of the lower expressed activity of CLEA- $\beta$-SPI- 2 compared to CLEA- $\beta$-BSA-5.

Figure 1 shows images of CLEA- $\beta$-SPI-12 using scanning electron microscopy, where it is possible to see the heterogeneity in the particle size (lower than $70 \mu \mathrm{m}$ ) of the prepared biocatalyst.

The activities obtained using both feeder proteins in the CLEA preparation were better than those reported in several studies employing $\beta$-amylases from different sources immobilized on preexisting supports. Vretblad and Axen [66] reported a global yield of $35 \%$ for barley $\beta$-amylase covalently attached on Sepharose activated with 4,4'-methylene dianiline. Tavano et al. [69] reported global yield of $21 \%$ for sweet potato $\beta$-amylase immobilized on glyoxyl-agarose support. These results are much closer to those obtained in our work for barley $\beta$-amylase ionically adsorbed on chitosan (Table 1). 


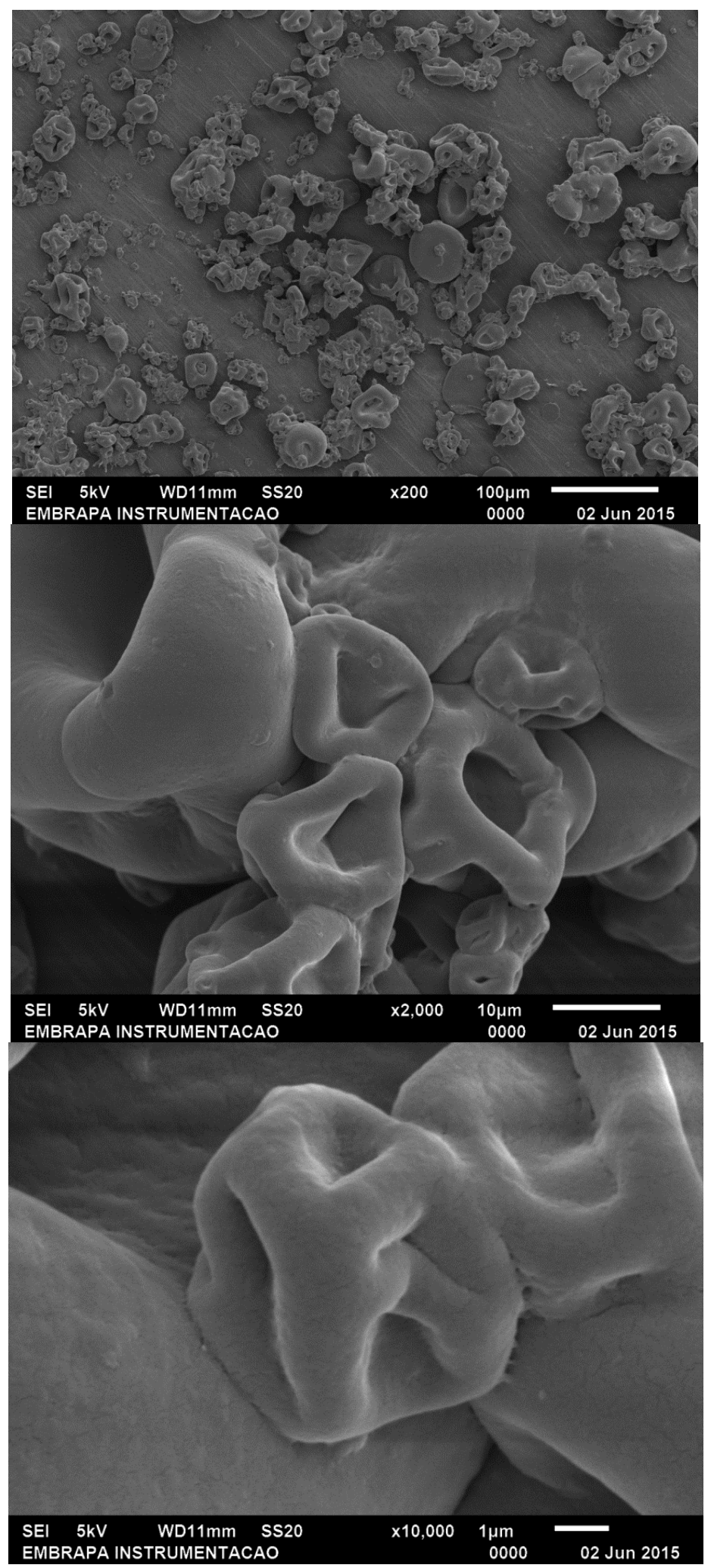

Figure 1. Images of CLEA- $\beta$-SPI-12 using scanning electron microscopy at different amplifications. 


\subsection{Effects of $\mathrm{pH}$ and Temperature on the Activity and the Stability of $\beta$-Amylase Preparations}

The study of the effect of the reaction $\mathrm{pH}$ and temperature on the enzyme activity of $\beta$-amylase was performed using free enzyme, CLEA- $\beta$-BSA- 5 and CLEA- $\beta$-SPI- 12 to investigate the influence of the enzyme immobilization technique on enzyme response to the medium [68-71] (Figure 2).

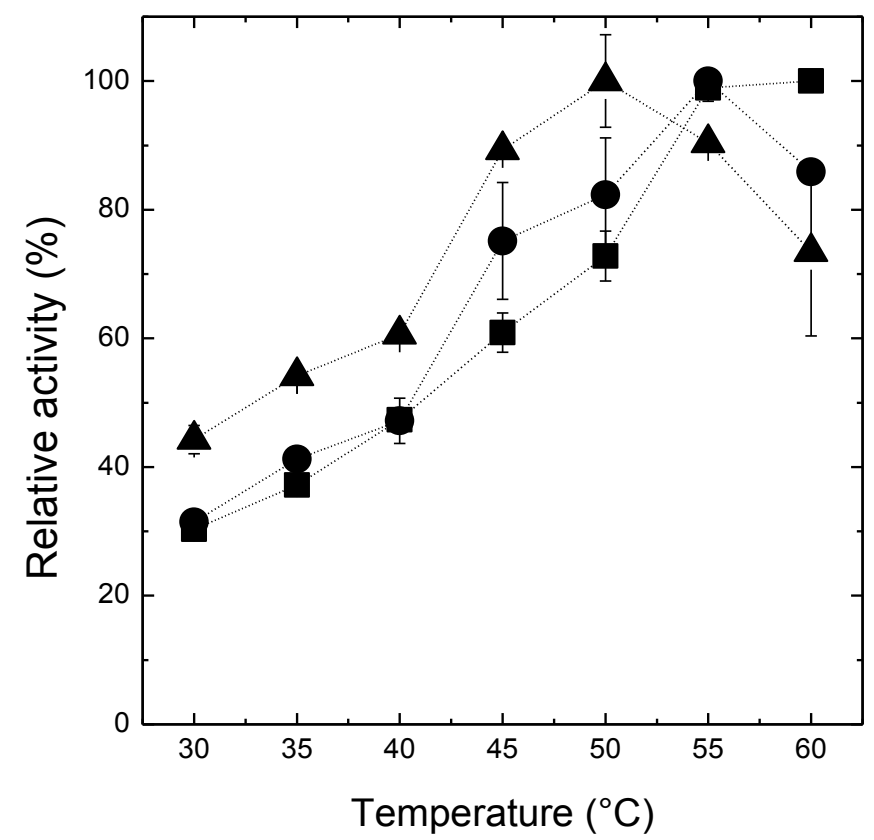

(a)

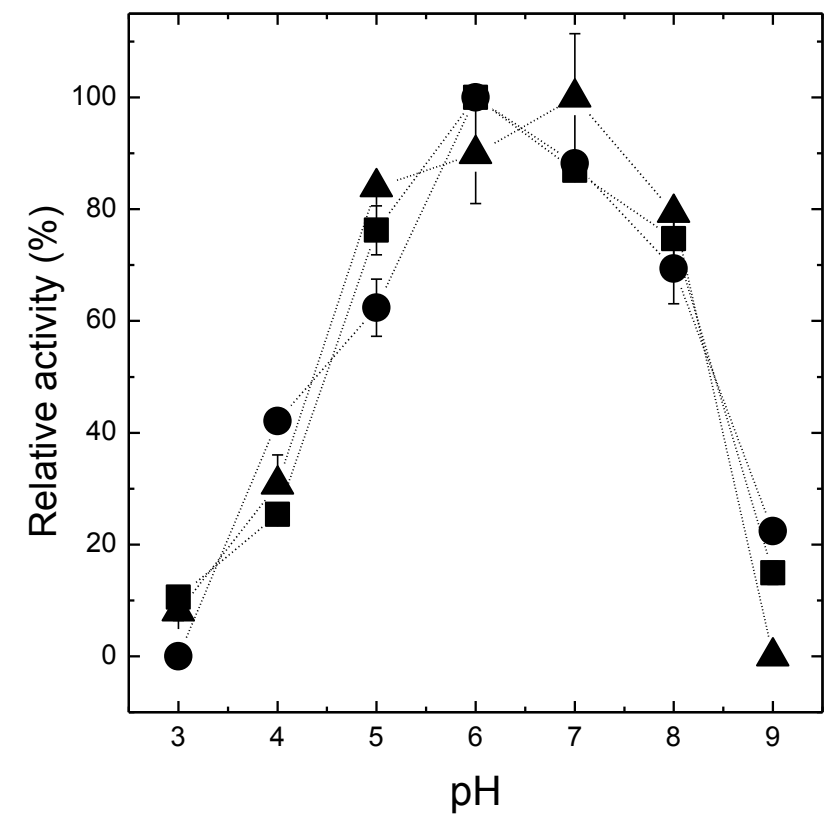

(b)

Figure 2. Temperature activity profile (a), using $1 \%(w / v)$ soluble starch solution at $\mathrm{pH} 4.8$ (standard condition for enzymatic assay as described in the Section 3.2) and $\mathrm{pH}$ activity profile (b), using $1 \%$ $(w / v)$ soluble starch solution at $20^{\circ} \mathrm{C}$, for free $\beta$-amylase (squares), CLEA- $\beta$-BSA- 5 (circles) and CLEA- $\beta$-SPI-12 (triangles). The maximum activities were taken as $100 \%$.

The effect of the temperature on the enzyme activity was similar for all $\beta$-amylase preparations (Figure 2a), expressing maximum activities in the range $50-55{ }^{\circ} \mathrm{C}$. In the case of CLEA- $\beta$-SPI-12, 
a small shift to lower temperature (approximately $5{ }^{\circ} \mathrm{C}$ ) of the maximum activity temperature was observed. It was expected that optimal $\mathrm{pH}$ and temperature of enzymes immobilized as CLEAs were shifted because covalent bonds established between amino groups of the enzyme and glutaraldehyde, changing the microenvironment and the conformational flexibility of the enzyme [49]. Talekar et al. [72] reported a shift to higher temperature (around $15^{\circ} \mathrm{C}$ ) for $\beta$-amylase from Bacillus amyloliquefaciens after immobilization by CLEA technique. However, Mafra et al. [58] reported the same maximum activity temperature for soluble and CLEAs of catalase. The effect of the $\mathrm{pH}$ on enzyme activity (Figure $2 \mathrm{~b}$ ) was similar for all enzymes, expressing maximum activity in the $\mathrm{pH}$ range 6.0-7.0. Talekar et al. [72] reported a pH shift from 6.0 to 7.0 for $\alpha$-amylase from B. amyloliquefaciens immobilized as CLEA, while Mafra et al. (2016) also reported a pH shift from 7.0 to 7.4 for catalase immobilized as CLEA with BSA as feeder protein. In our work, the $\mathrm{pH}$ shift from 6.0 to 7.0 for $\beta$-amylase immobilized as CLEA with SPI as feeder protein was not different statistically, considering the standard deviations (as provided by the $\mathrm{F}$ test).

Figure 3 a shows the residual activity after $12 \mathrm{~h}$ incubation at different $\mathrm{pH}$ values and $25^{\circ} \mathrm{C}$ of free $\beta$-amylase, CLEA- $\beta$-BSA- 5 and CLEA- $\beta$-SPI- 12 . In almost all cases, the free enzyme exhibited a slightly higher residual activity, followed by CLEA- $\beta$-BSA-5. The highest activity retained for each sample was observed at $\mathrm{pH} 7.0(96.0 \pm 0.6 \%), 6.0(88.2 \pm 3.5 \%)$ and $7.0(64.2 \pm 22.9 \%)$, for free $\beta$-amylase, CLEA- $\beta$-BSA- 5 and CLEA- $\beta$-SPI-12, respectively. Figure 3 a shows that at pH 5.0 (very similar to $\mathrm{pH} 4.8$ used in optimal temperature assay), the stability of free $\beta$-amylase is higher than those of CLEA- $\beta$-BSA- 5 and CLEA- $\beta$-SPI-12 (residual activities of $94.2 \pm 0.0,75.7 \pm 3.2$ and $45.1 \pm 2.2 \%$ respectively). This enzyme inactivation (especially high for CLEA- $\beta$-SPI-12) at acid $\mathrm{pH}$ value can explain the results observed in the effect of temperature on enzyme activity.

The temperature stability test was performed at the optimal $\mathrm{pH}$ for the stability of each $\beta$-amylase, pH 6.0 for CLEA- $\beta$-BSA- 5 and $\mathrm{pH} 7.0$ for free $\beta$-amylase and CLEA- $\beta$-SPI-12. Figure $3 \mathrm{~b}$ shows that at $40{ }^{\circ} \mathrm{C}$ free $\beta$-amylase and CLEA- $\beta$-SPI-12 did not present significant thermal deactivation after $12 \mathrm{~h}$ (109. $2 \pm 3.2$ and $96.1 \pm 5.5 \%$ of residual activity respectively). At $55^{\circ} \mathrm{C}$ the CLEAs retained some activity when the free enzyme was fully inactivated. The thermal stabilization observed at $55^{\circ} \mathrm{C}$ was reported for several enzymes immobilized as CLEAs by Sheldon [48] and Talekar et al. [49].

Although CLEA- $\beta$-BSA- 5 presented higher global yield and $\mathrm{pH}$ stability than CLEA- $\beta$-SPI-12, its stability at high temperatures was high. Also, the CLEA- $\beta$-BSA- 5 was more difficult to manipulate and separate from the very viscous reactional medium, containing a high sugar concentration. Thus, the CLEA- $\beta$-SPI-12 was chosen to be compared with free $\beta$-amylase on the maltose production assay.

\subsection{Maltose Production}

Maltose production was performed using soluble and residual cassava bagasse (enzymatically extracted) starches with free and CLEA- $\beta$-SPI-12 under the respective $\mathrm{pH}$ and temperature conditions where the biocatalysts exhibited optimal stabilities.

The residual starch solution was obtained via enzymatic extraction of cassava bagasse with starch content of $45.7 \pm 0.8 \%$ (d.m.). The high starch content in cassava bagasse from industrial mechanical extraction can be related, as explained in introduction, to the limitations of shear and broke the cassava root fibers to extract the starch [4] and this content can vary depending on cassava crop and processing conditions [2].

The maltose conversion by free $\beta$-amylase and CLEA- $\beta$-SPI-12 were compared using soluble starch solution containing $30.0 \mathrm{~g} / \mathrm{L}$ of commercial starch (dextrose equivalent, $\mathrm{DE} \approx 0$ ) and $36.0 \mathrm{U} / \mathrm{L}$, the equivalent of $1.2 \mathrm{U} / \mathrm{g}$ (enzymatic unit per gram of starch), for each enzyme preparation. Figure $4 \mathrm{a}$ shows that maltose conversion using free enzyme was faster than using CLEA- $\beta$-SPI- 12 . After $45 \mathrm{~min}$, the free enzyme achieved $44.5 \%$ of conversion, while CLEA- $\beta$-SPI- 12 presented the same conversion after $9 \mathrm{~h}$. The maximum conversions were $52.3 \pm 2.3$ (after $6 \mathrm{~h}$ ) and $46.4 \pm 5.4 \%$ (after $12 \mathrm{~h}$ ) for free $\beta$-amylase and CLEA- $\beta$-SPI-12, respectively. The productivities and specific productivities of both soluble starch conversions were $2.7 \pm 0.1$ and $1.2 \pm 0.1 \mathrm{~kg} / \mathrm{m}^{3} \mathrm{~h}$, and $75.9 \pm 3.3$ and $33.7 \pm 3.9 \mathrm{mg} / \mathrm{Uh}$ 
using free $\beta$-amylase and CLEA- $\beta$-SPI-12, respectively. Yoshigi et al. [73] reported $57.7 \%$ of starch conversion using free barley $\beta$-amylase and $5.0 \mathrm{~g} / \mathrm{L}$ soluble starch solution $(50 \mathrm{mM}$ acetate buffer, $\mathrm{pH}$ 5.5) incubated at temperature of $37^{\circ} \mathrm{C}$. This could be due to the high size of the starch used, as well as the low DE, probably causing diffusional limitations in the CLEA- $\beta$-SPI- 12 .

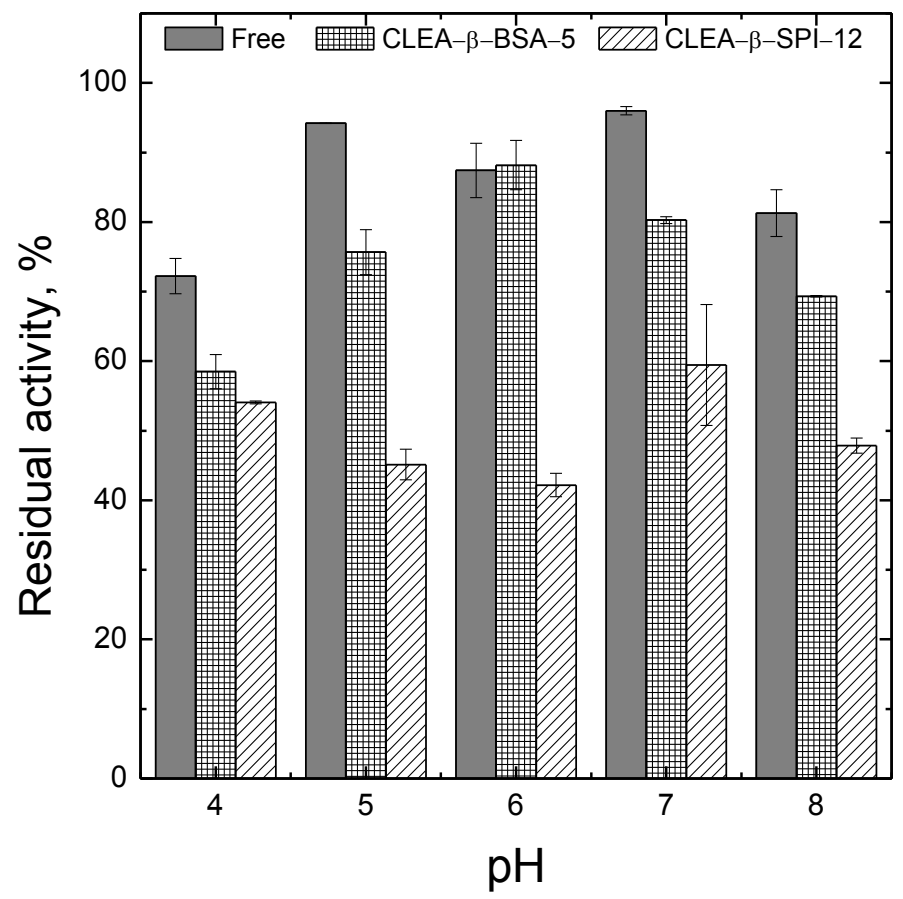

(a)

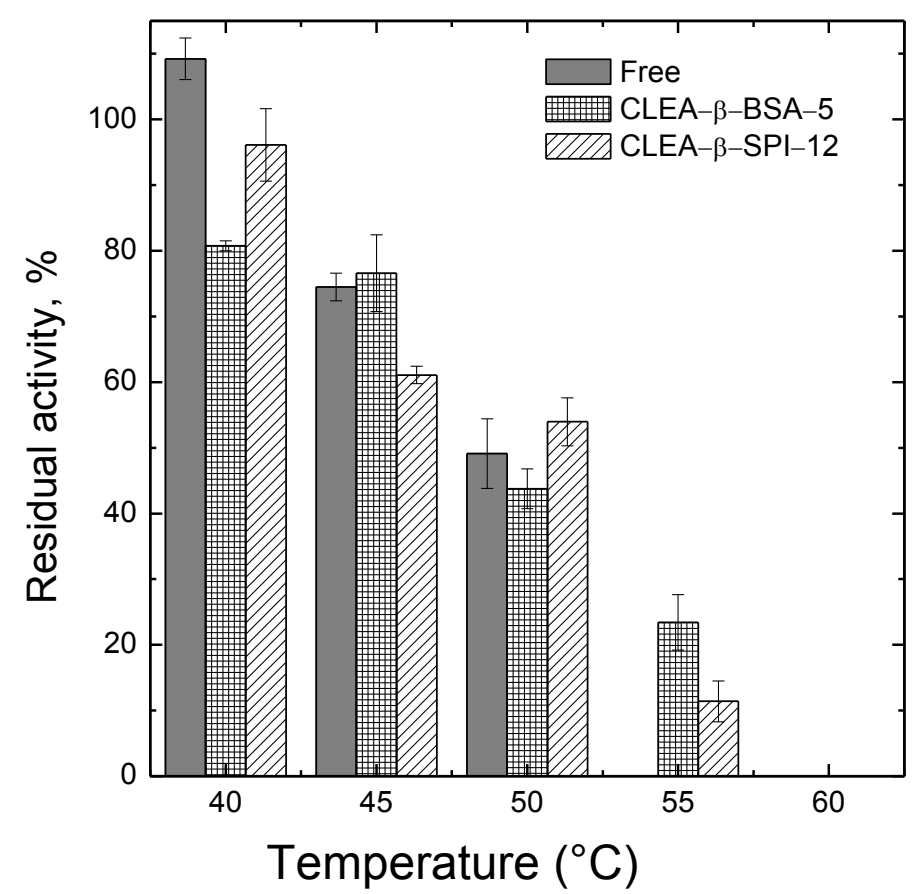

(b)

Figure 3. Residual activities of free $\beta$-amylase, CLEA- $\beta$-BSA- 5 and CLEA- $\beta$-SPI- 12 for $\mathrm{pH}$ stability (a) after $12 \mathrm{~h}$ of incubation at $25^{\circ} \mathrm{C}$ and temperature stability and, (b) after $12 \mathrm{~h}$ of incubation at $\mathrm{pH} 6.0$ (CLEA- $\beta$-BSA-5) and $\mathrm{pH} 7.0$ (free $\beta$-amylase and CLEA- $\beta$-SPI-12). $100 \%$ is the initial activity. 


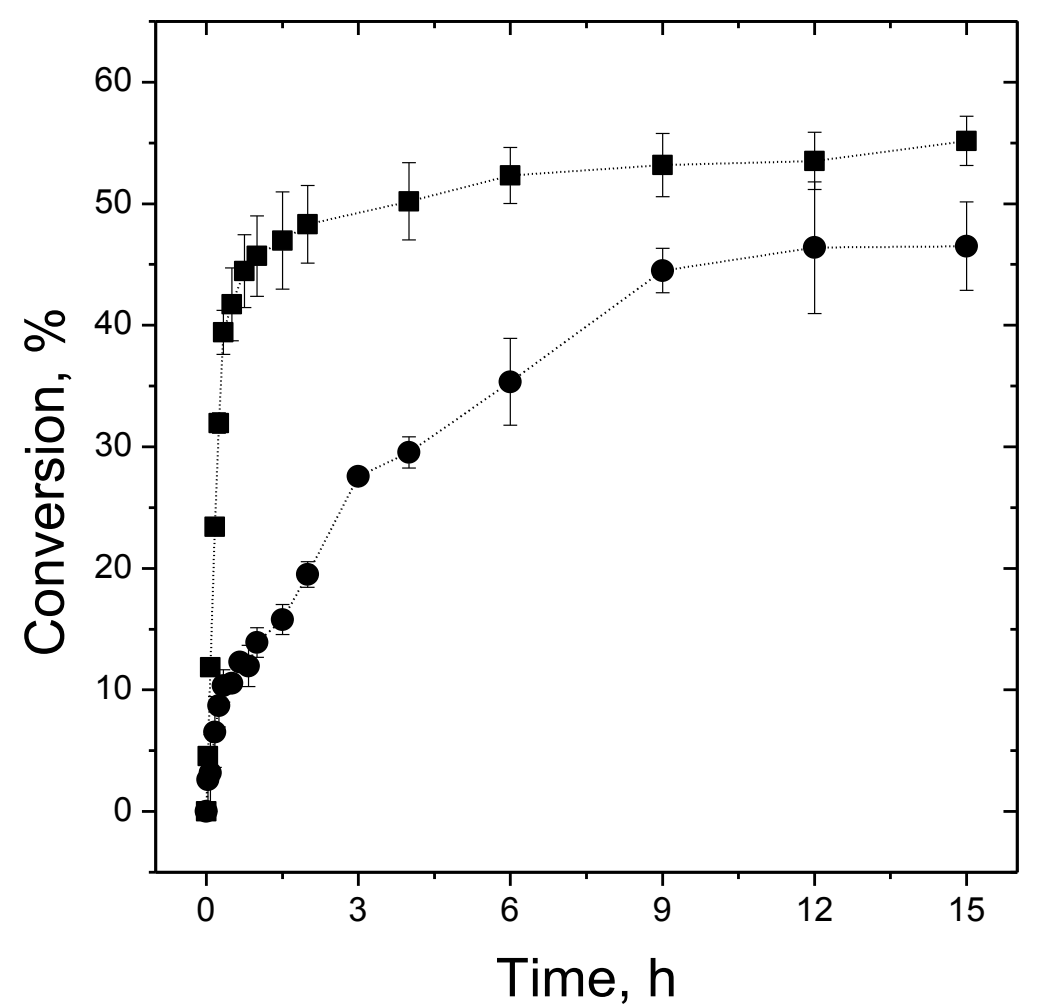

(a)

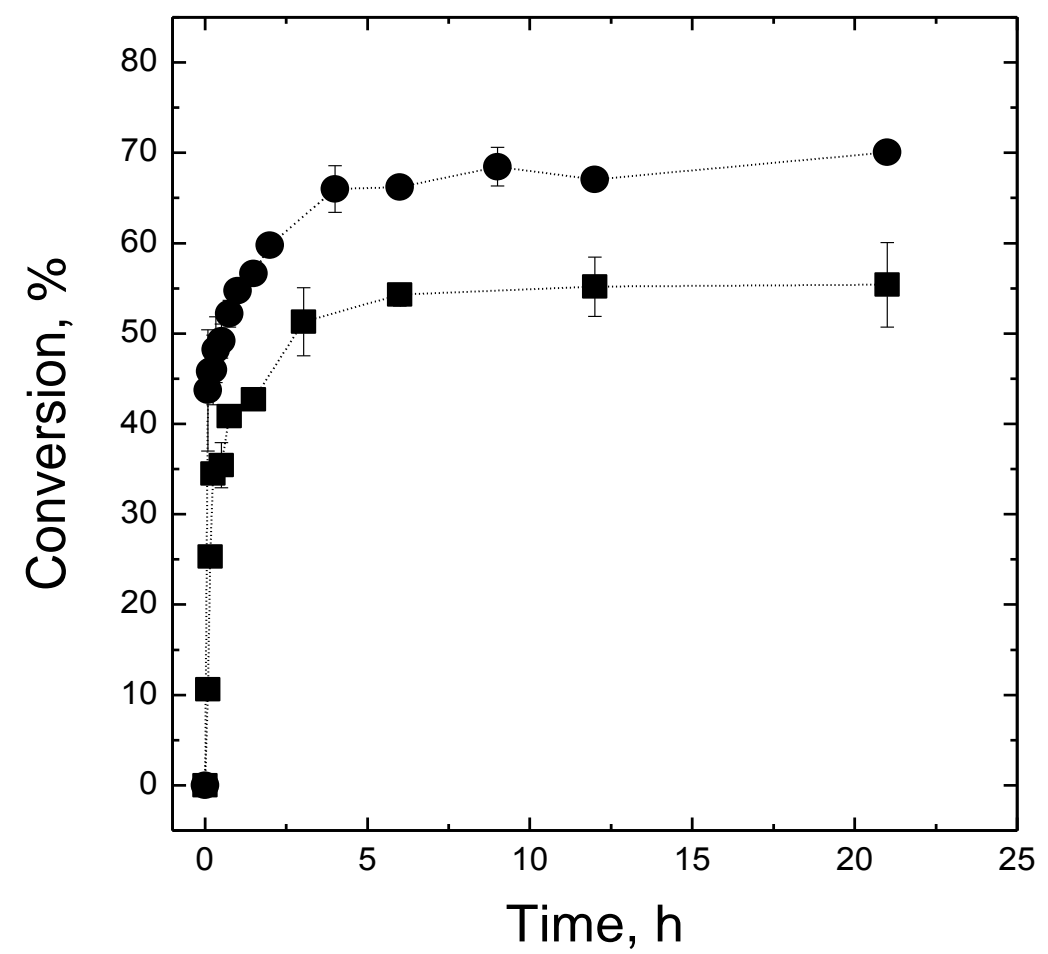

(b)

Figure 4. Comparative soluble starch $(30 \mathrm{~g} / \mathrm{L})$ conversion using free $\beta$-amylase (squares) and CLEA- $\beta$-PS-12 (circles) at $\mathrm{pH} 7.0$ and $40^{\circ} \mathrm{C}$; (a) comparative starch conversion using cassava bagasse starch solutions with free $\beta$-amylase (squares) and CLEA- $\beta$-PS-12 (circles), using $1.2 \mathrm{U} / \mathrm{g}$ of starch, pH 7.0 and $40^{\circ} \mathrm{C}(\mathbf{b})$. 
The assay using cassava bagasse starch solutions $30.0 \mathrm{~g} / \mathrm{L}$ (DE of 7.95 and 15.88) with free enzyme and CLEA- $\beta$-PS-12 (using $36 \mathrm{U} / \mathrm{L}$ ) reached maximum conversion of $54.3 \pm 1.2 \%$ and $66.0 \pm 2.6 \%$ at $6 \mathrm{~h}$ and $4 \mathrm{~h}$, respectively (Figure $4 \mathrm{~b}$ ). With both catalyst a higher maltose yield and activity was detected using this product (starch partially hydrolyzed extracted by $\alpha$-amylase action), very likely due to the very low DE using the commercial starch (near 0) compared to the high one of these home-obtained products (DE 8-16), offering more non-reducing ends to the enzyme action. Moreover, the lower size of the starch extracted from bagasse can reduce the diffusion limitations found using commercial starch, greatly improving the performance of the immobilized enzyme, that now overpass the free enzyme. The productivity and specific productivity of cassava bagasse starch conversions using free $\beta$-amylase and CLEA- $\beta$-PS-12 were $2.8 \pm 0.1$ and $5.2 \pm 0.2 \mathrm{~kg} / \mathrm{m} 3 \mathrm{~h}$, and $78.8 \pm 1.8$ and $143.7 \pm 5.6 \mathrm{mg} / \mathrm{Uh}$, respectively. The CLEA- $\beta$-PS-12 productivity and specific productivity using cassava bagasse starch solution with DE of 15.88 was 4.3 times higher than using soluble starch (DE near 0).

Gaouar et al. [74] used in this reaction a highly concentrated liquefied starch, $340 \pm 25 \mathrm{~g} / \mathrm{L}$ (DE unknown) and free Maltogenase $4000 \mathrm{~L}$ (from Bacillus subtilis) as biocatalyst, at $\mathrm{pH}$ values between 5.0 to 5.5 in a $1.0 \mathrm{~L}$ jacketed Pyrex cell with magnetic stirring, achieving $65.4 \%$ of maltose production, practically the same as using cassava bagasse residual starch with DE of 15.88 and CLEA- $\beta$-SPI- 12 . Shiraishi et al. [75] also achieved comparable starch conversion, using 150, 200 and $300 \mathrm{~g} / \mathrm{L}$ of liquefied white potato starch $(\mathrm{DE}=5.6)$ with $1.59 \mathrm{~g} / \mathrm{L}$ of free soybean $\beta$-amylase in a baffled flask with magnetic stirring at temperature of $40{ }^{\circ} \mathrm{C}$ and $\mathrm{pH} 4.8$, achieving a value of maltose content of $58.2 \%$ for all the tests.

CLEA- $\beta$-SPI-12 was utilized for four successive cycles of reaction (12 $\mathrm{h}$ reaction for each cycle) (Figure 5); the continuous decrease on yields becomes evident. The reasons for this may be the difficulty to capture the CLEAs in this very viscous media, even though the size of the biocatalyst was quite large, as enzyme inactivation under these conditions may be discarded in these very short reaction courses. The breakage of the CLEA particles during use will further increase this difficulty in the recovery, and that occurs even using a vortex reactor. In fact, Talekar et al. [72] also reported a reduction in the activity of CLEA of $\alpha$-amylase to around $65 \%$ of its original activity after four cycles of 30 min reaction at $60{ }^{\circ} \mathrm{C}$. They attributed the loss of activity to the substantial change in the CLEA morphology after four batches as shown by SEM images. In fact, in our work, the weight of CLEA obtained after the four reuses almost fit with the decreased activity. An alternative to improve the CLEA recovery may be to use magnetic nanoparticles trapped in the CLEAs to facilitate the capture [71,76-80]. Another possibility may be the trapping of the CLEAs in some larger and more rigid solids, e.g., lentikats $[81,82]$ or silica $[83,84]$.

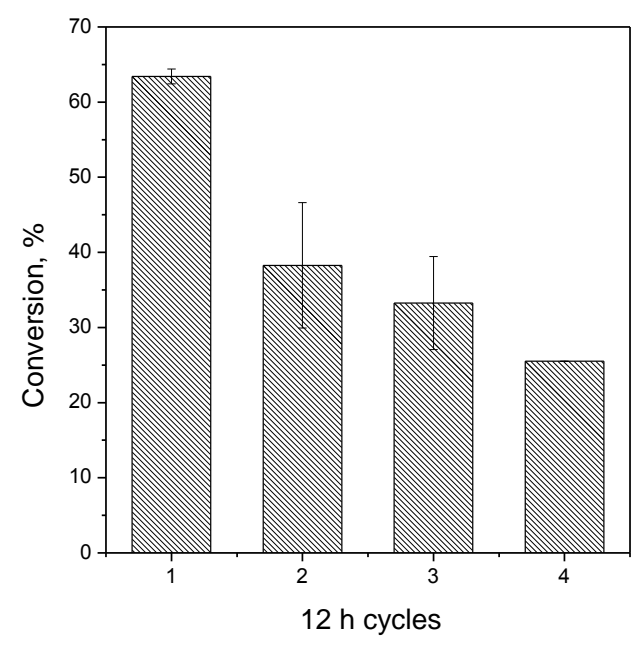

Figure 5. Reuse assays converting starch to maltose at $40{ }^{\circ} \mathrm{C}, \mathrm{pH} 7.0$ in a vortex flow reactor stirred at $900 \mathrm{rpm}$, using cassava bagasse starch solution (8.2 g/L) and CLEA- $\beta$-PS-12 (36.0 U/L). 


\section{Materials and Methods}

\subsection{Materials}

Cassava bagasse was supplied by Tereos Syral (Palmital, Brazil), soluble starch was purchased from Sigma-Aldrich (St. Louis, MO, USA). The $\alpha$-amylases Termamyl 120 L from Bacillus licheniformis and BAN 480 LS from Bacillus amyloliquefaciens were supplied by LNF Latino Americana (Bento Gonçalves, Brazil). Crude extract of barley $\beta$-amylase (type II-B) and bovine serum albumin (BSA, 96\% purity) were purchased from Sigma-Aldrich (St. Louis, MO, USA). Soy protein isolate (SPI, 90\% purity) was purchased from Doremus Ingredientes (Guarulhos, Brazil). Other reagents were of analytical grade.

\subsection{Enzymatic Activity Assay}

The activity of $\beta$-amylase was determinate according to Bernfeld [85] by measuring the initial velocity of maltose production. A solution of $1 \%(w / v)$ soluble starch in $16 \mathrm{mM}$ sodium acetate buffer ( $\mathrm{pH} 4.8$ ) was used as substrate. Free or immobilized $\beta$-amylase was added to the reaction medium, which was thermostatically equilibrated at $20{ }^{\circ} \mathrm{C}$ in a batch reactor. Periodically, sample aliquots were withdrawn until $12 \mathrm{~min}$ and the maltose content was quantified by the dinitrosalicylic acid method [86] using pure commercial maltose as standard. An enzymatic unit of $\beta$-amylase (U) was defined as the amount of enzyme required to release $1.0 \mathrm{mg}$ of maltose per minute under the assay conditions.

\section{3. $\beta$-Amylase Immobilization Using CLEA Technique}

A set of experiments were carried out using $0.5 \mathrm{~mL}$ of BSA or SPI solution (feeder protein), with concentrations values described in Table 3 , and $0.5 \mathrm{~mL}$ of $100 \mathrm{mM}$ sodium phosphate buffer at $\mathrm{pH} 7.0$ containing $2.0 \mathrm{mg}$ of protein/mL of $\beta$-amylase. Then, $1.0 \mathrm{~mL}$ of $5.0 \mathrm{M}$ ammonium sulfate solution was added to precipitate the proteins; after 5 min stirring 24.0 or $48.0 \mu \mathrm{L}$ of $25 \%(w / w)$ glutaraldehyde aqueous solution were added, reaching a glutaraldehyde final concentration of 30.0 or $60.0 \mathrm{mM}$, respectively. The protein suspension was kept under $200 \mathrm{rpm}$ stirring at $4{ }^{\circ} \mathrm{C}$ for $3 \mathrm{~h}$. Finally, the CLEA of $\beta$-amylase was separated from the supernatant by centrifugation at $21,000 \times \mathrm{g}$ and $4{ }^{\circ} \mathrm{C}$, washed with $100 \mathrm{mM}$ sodium phosphate buffer $\mathrm{pH} 7.0$, centrifuged again and resuspended in $1.0 \mathrm{~mL}$ of $100 \mathrm{mM}$ sodium phosphate buffer $\mathrm{pH} 7.0$ for $\beta$-amylase activity measurement.

The global yield was calculated according to Equation (1):

$$
\text { Global yeld }(\%)=\frac{\text { CLEA activity }}{\text { Initial activity }} \times 100,
$$

where the CLEA activity is the observed activity in the CLEA after centrifugation, washing (2 times with $1.0 \mathrm{~mL}$ of $100 \mathrm{mM}$ phosphate buffer $\mathrm{pH}$ 7.0) and resuspension in the same washing buffer; initial activity is the total activity offered to the immobilization.

\subsection{Immobilizations on Chitosan Based Supports by Adsorption, Covalent Attachment and Encapsulation}

$\beta$-amylase was immobilized on chitosan according to Vieira et al. [87], with chitosan-based matrices of $2.0 \%$ (for adsorption and covalent attachment) and $1.0 \%$ (for encapsulation) ( $w / w$ ), aiming to achieve bigger pore sizes. The amount of enzyme supplied for immobilization was $0.53 \mathrm{mg}$ of protein per gram of chitosan. Table 4 shows the conditions for chitosan-based immobilizations.

Chitosan powder was solubilized in $2.0 \%(v / v)$ acetic acid solution and coagulated using $0.5 \mathrm{M}$ potassium hydroxide solution (volume ratio chitosan: $\mathrm{KOH}$ solutions of 2:3). The suspension was stirred at $50{ }^{\circ} \mathrm{C}$ for $30 \mathrm{~min}$ to form flakes. The flakes were filtrated and washed with Milli-Q water and $5 \mathrm{mM}$ sodium phosphate buffer $\mathrm{pH}$ 7.0. 
Table 3. Conditions of preparation of CLEAs of $\beta$-amylase using bovine serum albumin (BSA) and soy protein isolate (SPI) as cofeeder and glutaraldehyde as crosslinker.

\begin{tabular}{|c|c|c|c|c|}
\hline Assay ${ }^{1}$ & Feeder Protein & $\begin{array}{c}\text { Cofeeder Concentration }{ }^{2} \\
(\mathrm{mg} / \mathrm{mL})\end{array}$ & $\begin{array}{c}\text { Glutaraldehyde } \\
\text { Concentration }{ }^{3}(\mathrm{mM})\end{array}$ & $\begin{array}{c}\text { Glutaraldehyde/Total } \\
\text { Protein }{ }^{4} \text { Ratio }(\mathrm{mM} / \mathrm{mg})\end{array}$ \\
\hline 1 & None & 0 & 30 & 60.0 \\
\hline 3 & \multirow{6}{*}{ BSA } & 160 & 30 & 0.74 \\
\hline 4 & & 120 & 30 & 0.98 \\
\hline 5 & & 80 & 30 & 1.46 \\
\hline 8 & & 120 & 60 & 1.97 \\
\hline 9 & & 80 & 60 & 2.93 \\
\hline 10 & & 40 & 60 & 5.71 \\
\hline 11 & \multirow{6}{*}{ SPI } & 80 & 30 & 1.46 \\
\hline 12 & & 60 & 30 & 1.93 \\
\hline 16 & & 60 & 60 & 3.87 \\
\hline 17 & & 40 & 60 & 5.71 \\
\hline 18 & & 30 & 60 & 7.50 \\
\hline 19 & & 20 & 60 & 10.91 \\
\hline
\end{tabular}

${ }^{1}$ All assays were carried out at $4{ }^{\circ} \mathrm{C}$ and amonium sulfate solution $(5 \mathrm{M})$ was used to precipitate the proteins.

${ }^{2}$ Feeder protein concentration in water solution; ${ }^{3}$ Glutaraldehyde concentration in protein solution $(2 \mathrm{mg} / \mathrm{mL})$, prepared in $100 \mathrm{mM}$ sodium phosphate buffer $\mathrm{pH} 7.0 .{ }^{4}$ Total amount of enzyme and cofeeder (BSA or SPI).

Table 4. Conditions for adsorption, covalent attachment and encapsulation in chitosan using $0.53 \mathrm{mg}$ of protein (crude enzyme) per gram of chitosan.

\begin{tabular}{ccccc}
\hline $\begin{array}{c}\text { Immobilization } \\
\text { Method }\end{array}$ & Adsorption & $\begin{array}{c}\text { Adsorption Followed } \\
\text { by Crosslinking }\end{array}$ & $\begin{array}{c}\text { Covalent } \\
\text { Attachment }\end{array}$ & Encapsulation \\
\hline $\begin{array}{c}\text { Carrier } \\
\text { Glutaraldehyde } \\
\text { concentration }\end{array}$ & Chitosan $2 \mathrm{wt} \%$ & Chitosan $2 \mathrm{wt} \%$ & Chitosan $2 \mathrm{wt} \%$ & Chitosan $1 \mathrm{wt} \%$ \\
$\begin{array}{c}\text { Temperature }\left({ }^{\circ} \mathrm{C}\right) \\
\text { Stirring }\end{array}$ & 0 & $0.15 \%$ & $0.80 \%$ & $0.10 \%$ \\
\hline
\end{tabular}

The $\beta$-amylase adsorption was performed in a shaker at $25{ }^{\circ} \mathrm{C}$ and $100 \mathrm{rpm}$, suspending $1 \mathrm{~g}$ of chitosan flakes in $5 \mathrm{~mL}$ of enzyme solution ( $0.53 \mathrm{mg}$ of $\beta$-amylase/g of chitosan), prepared in $5 \mathrm{mM}$ sodium phosphate buffer $\mathrm{pH}$ 7.0. The immobilization was monitored by measuring the enzyme activity in the supernatant and suspension, using an identical enzyme solution without chitosan as blank reference. At the end, the immobilization yield was determined (Equation (2)), then the flakes were filtrated, washed with distilled water and the expressed activity (Equation (3)) and the global yield (Equation (4)) were calculated. We also determined the global yield of the adsorbed enzyme after treatment with $0.15 \%(v / v)$ glutaraldehyde solution under mild stirring, at room temperature for $1 \mathrm{~h}$ at $\mathrm{pH}$ 7.0.

For covalent immobilization, firstly the chitosan flakes were activated with $0.8 \%(v / v)$ glutaraldehyde solution at $\mathrm{pH} 7.0$ under mild stirring for $30 \mathrm{~min}$, followed by washing with Milli-Q water and $100 \mathrm{mM}$ sodium phosphate buffer at $\mathrm{pH}$ 7.0. The immobilization of $\beta$-amylase on activated chitosan was carried out in $100 \mathrm{mM}$ sodium phosphate buffer $\mathrm{pH} 7.0$ (1:5 solid/liquid ratio, $0.53 \mathrm{mg}$ of $\beta$-amylase/g of chitosan, as in the adsorption method) at $25{ }^{\circ} \mathrm{C}$ and $100 \mathrm{rpm}$ stirring, monitoring the supernatant, suspension and blank reference. The immobilization yield, expressed activity and the global yield were calculated as described above.

For the encapsulation into chitosan, chitosan powder was solubilized in $2.0 \%(v / v)$ acetic acid solution and homogenized under stirring at room temperature for $1 \mathrm{~h}$. Then the $\mathrm{pH}$ was adjusted 
to 4.35 using sodium hydroxide solution and the $\beta$-amylase was added. This solution was added dropwise into a $100 \mathrm{mM}$ Tris- $\mathrm{HCl}$ buffer $\mathrm{pH} 8.0$ (in ice bath) in a volume ratio chitosan solution:buffer of 1:10, under mild stirring for $30 \mathrm{~min}$. After, glutaraldehyde $25 \%(w / w)$ was added to achieve a final concentration of $0.1 \%(v / v)$ and the reaction occurred under mild stirring at room temperature for $2 \mathrm{~h}$. The chitosan gels were filtrated, washed with distilled water and $100 \mathrm{mM}$ sodium phosphate buffer $\mathrm{pH}$ 7.0, and the global yield was calculated by Equation (4).

The immobilization yield and expressed activity for adsorption and covalent attachment on chitosan were calculated according to Equations (2) and (3), respectively:

$$
\begin{gathered}
\text { Immobilization yield }(\%)=\frac{\text { Immobilized activity }}{\text { Initial activity }} \times 100, \\
\text { Expressed activity }(\%)=\frac{\text { Derivative activity }}{\text { Immobilized activity }} \times 100,
\end{gathered}
$$

where the immobilized activity is the initial activity offered to the immobilization minus the activity in the final supernatant. Derivative activity is the activity measured in the immobilized enzyme.

The global yield was calculated according Equation (4):

$$
\text { Global yield }(\%)=\frac{\text { Derivative activity }}{\text { Initial activity }} \times 100,
$$

\subsection{Effect of $\mathrm{pH}$ and Temperature on Activity and Stability of $\beta$-Amylase Preparations}

The enzymatic activity of immobilized or free enzyme was determined at different $\mathrm{pH}$ values and $20{ }^{\circ} \mathrm{C}$ as described in the Section 3.2, using different buffers $(16 \mathrm{mM})$ : sodium acetate buffer at $\mathrm{pH}$ values from 3.0 to 5.0, sodium phosphate buffer at $\mathrm{pH}$ values from 6.0 to 8.0 or sodium carbonate buffer at $\mathrm{pH} 9.0$.

To determinate the optimum activity temperature of free or immobilized $\beta$-amylase, the enzymatic activity was measured using $16 \mathrm{mM}$ sodium acetate buffer at $\mathrm{pH} 4.8$ in a temperature range from 30 to $60^{\circ} \mathrm{C}$.

For the stability assays, free and CLEAs of $\beta$-amylase samples were incubated at the indicated temperature and $\mathrm{pH}$ values for $12 \mathrm{~h}$ under $200 \mathrm{rpm}$ stirring. The $\mathrm{pH}$ stability assay was studied at $25{ }^{\circ} \mathrm{C}$ and $\mathrm{pH}$ values from 4.0 to 8.0 , using the same buffers of the $\mathrm{pH}$ effect on activity assay. The temperature stability assay was performed incubating the samples in the buffer of highest stability for each sample (free or CLEAs $\beta$-amylase) and temperatures from 40 to $60^{\circ} \mathrm{C}$. The relative residual activity was calculated as the ratio between the activity after the incubation and the initial activity.

\subsection{Cassava Bagasse Compositional Analysis}

Starch was extracted from cassava bagasse using $0.625 \mathrm{~mL}$ of $\alpha$-amylase (Termamyl $120 \mathrm{~L}$ ) per $\mathrm{g}$ of bagasse (dry mass) in $50.0 \mathrm{~mL}$ of water, at $90{ }^{\circ} \mathrm{C}$, with $540 \mathrm{rpm}$ mechanic stirring for $2 \mathrm{~h}$ [88]. Then, the reactional medium was filtrated to remove the solid fraction. The liquid fraction, containing mainly maltodextrins, was submitted to acid hydrolysis $(1.0 \mathrm{~mL}$ of $72 \%(v / v)$ sulfuric acid to $22.5 \mathrm{~mL}$ of maltodextrin solution) in an autoclave for $30 \mathrm{~min}$ to produce glucose monomers [89]. The acid hydrolysis in an autoclave can also generate a small amount of hydroxymethylfurfural (HMF) molecules. Glucose was quantified by liquid chromatography in a Shimadzu chromatograph equipped with a refractive index detector (RID) at $50{ }^{\circ} \mathrm{C}$, using a BioRad Aminex HPX-87H column $(300 \times 7.8 \mathrm{~mm})$ set to $65^{\circ} \mathrm{C}$ and $5 \mathrm{mM}$ sulfuric acid solution as eluent with a flow of $0.6 \mathrm{~mL} / \mathrm{min}$. HMF was quantified in a Shimadzu Chromatograph equipped with a UV-Visible detector (set to $274 \mathrm{~nm})$ using a SunFire C18 column $(4.6 \times 150 \mathrm{~mm})$ at $40^{\circ} \mathrm{C}$ and acetonitrile-water solution $(1: 8 \mathrm{v} / \mathrm{v})$, containing $1 \%(v / v)$ acetic acid, as mobile phase at $0.8 \mathrm{~mL} / \mathrm{min}$ flow rate. The amount of glucose and HMF was used to calculate the total amount of extractable starch from cassava bagasse. 


\subsection{Residual Starch Extraction}

The residual starch contained in cassava bagasse was gelatinized in $50 \mathrm{mM}$ sodium phosphate buffer $\mathrm{pH} 7.0$ (28.0 $\mathrm{g}$ of starch/L) under stirring in boiling water bath for $10 \mathrm{~min}$. The bagasse suspension was cooled to $60^{\circ} \mathrm{C}$ and the $\mathrm{pH}$ was adjusted to 6.0 using diluted $\mathrm{HCl}$ solution. Then $12.6 \mathrm{~mL}$ of $\alpha$-amylase (BAN $480 \mathrm{LS}$ ) per $\mathrm{kg}$ of starch was added to the bagasse suspension, the medium was stirred for $5 \mathrm{~min}$, and the reaction was stopped by adding a $50 \%(v / v) \mathrm{HCl}$ solution to the reactional medium (1:333 volume ratio). The medium was filtrated at $60^{\circ} \mathrm{C}$, the starch concentration and dextrose equivalent $(\mathrm{DE}=100 \times$ amount of reducing sugar expressed as glucose/solid dry mass) were quantified and, if necessary, the soluble starch was diluted or concentrated. DE is a measure of polymerization degree of the starch chains, using glucose as pattern. When the DE value is near to zero the polymerization degree is very high, the starch molecules have high molecular weight. When the $\mathrm{DE}$ value is near to 100 the polymerization degree is very low, the starch molecules were practically converted into glucose [7].

The amount of reducing sugar was determinate by DNS method [86] using glucose as standard.

\subsection{Maltose Production}

The enzymatic maltose production was performed in a batch Taylor vortex flow reactor (VFR) [90] with radius ratio $(\eta=\mathrm{Ri} / \mathrm{Re})$ of 0.24 , aspect ratio $(\Gamma=\mathrm{L} / \mathrm{d})$ of 6.32 and inner cylinder rotation rate $(\omega)$ of $900 \mathrm{rpm}$, using $50.0 \mathrm{~mL}$ of commercial starch solution or residual starch solution extracted from cassava bagasse and 36.0 U/L of free or CLEA of $\beta$-amylase, at $\mathrm{pH}$ and temperature values of maximum stability (determined as described before). The starch conversion was followed by the increase of maltose concentration during the reaction time. Samples of the reactional medium were treated with $1.0 \mathrm{M} \mathrm{HCl}(50: 3 \mathrm{v} / \mathrm{v})$ to inactivate the enzymes in the sample, the maltose concentrations were determinate by HPLC (Shimadzu Chromatograph, using a BioRad Aminex HPX-87H column and $5 \mathrm{mM}$ sulfuric acid solution at $0.6 \mathrm{~mL} / \mathrm{min}$ as eluent, as described above for glucose quantification) and the starch conversion was calculated using $0.957 \mathrm{~g}$ of starch $/ \mathrm{g}$ of maltose as conversion factor.

\subsection{Reuse Assays}

The reuse assays were performed using the same conditions for maltose production catalyzed by CLEA of $\beta$-amylase. Each batch was carried out for $12 \mathrm{~h}$ reaction, being the maltose conversion determined in the end of each batch. Between each reactional cycle the biocatalyst was separated by centrifugation $\left(15,370 \times g\right.$ at $4{ }^{\circ} \mathrm{C}$ for $\left.10 \mathrm{~min}\right)$ and washed with distilled water.

\subsection{Protein Assay}

The protein concentrations of $\beta$-amylase extracts were determined according to the Bradford's method [91] using BSA as the standard protein.

\section{Conclusions}

This study showed that barley $\beta$-amylase can be immobilized by CLEA technology and can achieve a higher global yield than other strategies used to immobilize this $\beta$-amylases. Soy protein isolated could be used as feeder protein for barley $\beta$-amylase CLEA, creating an immobilized enzyme cheaper and easier to manipulate than using bovine serum albumin as feeder protein. The use of soy protein isolated as an alternative as feeder protein could reduce the cost of the CLEAs biocatalyst production when a feeder is required. The bagasse-starch conversion using CLEA- $\beta$-SPI- 12 reached maximum starch conversion even slightly better that that obtained by using free $\beta$-amylase, and achieved high starch conversion similar to the best results reported in the literature in a short period of time. This study also shows that the cassava bagasse could be used as starch source for maltose production, giving this residue a new and more profitable use. CLEAs recovering in this viscous medium become a problem that should be attacked using different strategies, e.g., use of magnetic 
nanoparticles, trapping of the CLEAs in larger and more rigid solids, easier to recover in this very viscous medium.

Acknowledgments: The authors thank Tereos Syral (Palmital, Brazil) for the donation of cassava bagasse and LNF Latino Americana (Bento Gonçalves, Brazil) for the donation of $\alpha$-amylases (Termamyl 120 L and BAN 480 LS). We gratefully recognize the support from the São Paulo Foundation (FAPESP), National Council for Scientific and Technology Development (CNPq) and Coordination for the Improvement of Higher Level or Education Personnel (CAPES, doctorate fellowship of R. A. Silva) from Brazilian Government, and MINECO from Spanish Government, (project number CTQ2017-86170-R). Ángel Berenguer's (Instituto Universitario de Materiales, Universidad de Alicante) help and suggestions during the writing of this paper are gratefully recognized.

Author Contributions: Rafael Araujo-Silva performed all experimental assays; Agnes Cristina Oliveira Mafra and Willian Kopp help to prepare the CLEAs; Mayerlenis Jimenez Rojas helped in the starch extraction and its characterization; Roberto de Campos Giordano, Roberto Fernandez-Lafuente and Paulo Waldir Tardioli designed and supervised all experiments, as well as wrote/reviewed the manuscript with help of Rafael Araujo-Silva as part of his Masters of Science in Chemical Engineering. All authors have given approval to the final version of the manuscript.

Conflicts of Interest: The authors declare no conflicts of interest.

\section{References}

1. Food and Agriculture Organization (FAO). Food Outlook—Biannual Report on Global Food Markets; FAO: Rome, Italy, 2017; Volume November.

2. Pandey, A.; Soccol, C.R.; Nigam, P.; Soccol, V.T.; Vanderberghe, L.P.S.; Mohan, R. Biotechnological potential of agro-industrial residues: II cassava bagasse. Bioresour. Technol. 2000, 74, 81-87. [CrossRef]

3. Leonel, M.; Cereda, M.P. Starch extration from cassava fibrous residue. Ciência e Tecnol. Aliment. 2000, 20, 122-127. [CrossRef]

4. Sriroth, K.; Chollakup, R.; Chotineeranat, S.; Piyachomkwan, K.; Oates, C.G. Processing of cassava waste for improved biomass utilization. Bioresour. Technol. 2000, 71, 63-69. [CrossRef]

5. Prado, I.N.; Martins, A.D.S.; Alcalde, C.R.; Zeoula, L.M.; Marques, J.D.A. Performance of heifers fed diets containing corn or cassava hull as energy source and cottonseed meal or yeast as protein source. Rev. Bras. Zootec. 2000, 29, 278-287. [CrossRef]

6. Piddocke, M.P.; Kreisz, S.; Heldt-Hansen, H.P.; Nielsen, K.F.; Olsson, L. Physiological characterization of brewer's yeast in high-gravity beer fermentations with glucose or maltose syrups as adjuncts. Appl. Microbiol. Biotechnol. 2009, 84, 453-464. [CrossRef] [PubMed]

7. BeMiller, J.N.; Huber, K.C. Carbohydrates. In Fennema's Food Chemistry; Damodaran, S., Parkin, K.L., Fennema, O.R., Eds.; CRC Press: Boca Raton, FL, USA, 2007; pp. 83-151.

8. Synowiecki, J. The use of starch processing enzymes in the food industry. In Industrial Enzymes; Polaina, J., MacCabe, A.P., Eds.; Springer: Dordrecht, The Netherlands, 2007; ISBN 9781402053764.

9. Das, R.; Mishra, H.; Srivastava, A.; Kayastha, A.M. Covalent immobilization of beta-amylase onto functionalized molybdenum sulfide nanosheets, its kinetics and stability studies: A gateway to boost enzyme application. Chem. Eng. J. 2017, 328, 215-227. [CrossRef]

10. Ma, Y.; Stewart, D.C.; Eglinton, J.K.; Logue, S.J.; Langridge, P.; Evans, D.E. Comparative Enzyme Kinetics of Two Allelic Forms of Barley (Hordeum vulgare L.) Beta -amylase. J. Cereal Sci. 2000, 31, 335-344. [CrossRef]

11. Baker, W.L.; Smiley, K.L. Beta-amylase sulphydryl and disulphide group reactions. Additional aspects on enzyme inhibition by ascorbic acid. J. Inst. Brew. 1985, 91, 25-30. [CrossRef]

12. Mikami, B.; Yoon, H.; Yoshigi, N. The Crystal Structure of the Sevenfold Mutant of Barley $\beta$-Amylase with Increased Thermostability at $2.5 \AA$ A Resolution. J. Mol. Biol. 1999, 285, 1235-1243. [CrossRef] [PubMed]

13. Yoshigi, N.; Okada, Y.; Maeba, H.; Sahara, H.; Tamaki, T. Construction of a Plasmid Used for the Expression of a Sevenfold-Mutant Barley $\beta$-Amylase with Increased Thermostability in Escherichia coli and Properties of the Sevenfold-Mutant $\beta$-Amylase. J. Biochem. 1995, 118, 562-567. [CrossRef] [PubMed]

14. Brady, D.; Jordaan, J. Advances in enzyme immobilisation. Biotechnol. Lett. 2009, 31, 1639-1650. [CrossRef] [PubMed]

15. Cantone, S.; Ferrario, V.; Corici, L.; Ebert, C.; Fattor, D.; Spizzo, P.; Gardossi, L. Efficient immobilisation of industrial biocatalysts: Criteria and constraints for the selection of organic polymeric carriers and immobilisation methods. Chem. Soc. Rev. 2013, 42, 6262-6276. [CrossRef] [PubMed] 
16. DiCosimo, R.; McAuliffe, J.; Poulose, A.J.; Bohlmann, G. Industrial use of immobilized enzymes. Chem. Soc. Rev. 2013, 42, 6437-6474. [CrossRef] [PubMed]

17. Sheldon, R.A.; van Pelt, S. Enzyme immobilisation in biocatalysis: Why, what and how. Chem. Soc. Rev. 2013, 42, 6223-6235. [CrossRef] [PubMed]

18. Garcia-Galan, C.; Berenguer-Murcia, Á.; Fernandez-Lafuente, R.; Rodrigues, R.C. Potential of different enzyme immobilization strategies to improve enzyme performance. Adv. Synth. Catal. 2011, 353, 2885-2904. [CrossRef]

19. Guzik, U.; Hupert-Kocurek, K.; Wojcieszyńska, D. Immobilization as a Strategy for Improving Enzyme Properties-Application to Oxidoreductases. Molecules 2014, 19, 8995-9018. [CrossRef] [PubMed]

20. Mateo, C.; Palomo, J.M.; Fernandez-Lorente, G.; Guisan, J.M.; Fernandez-Lafuente, R. Improvement of enzyme activity, stability and selectivity via immobilization techniques. Enzyme Microb. Technol. 2007, 40, 1451-1463. [CrossRef]

21. Balcão, V.M.; Vila, M.M.D.C. Structural and functional stabilization of protein entities: State-of-the-art. Adv. Drug Deliv. Rev. 2015, 93, 25-41. [CrossRef] [PubMed]

22. Iyer, P.V.; Ananthanarayan, L. Enzyme stability and stabilization-Aqueous and non-aqueous environment. Process Biochem. 2008, 43, 1019-1032. [CrossRef]

23. Rodrigues, R.C.; Ortiz, C.; Berenguer-Murcia, A.; Torres, R.; Fernández-Lafuente, R.; Berenguer-Murcia, Á.; Torres, R.; Fernández-Lafuente, R. Modifying enzyme activity and selectivity by immobilization. Chem. Soc. Rev. 2013, 42, 6290-6307. [CrossRef] [PubMed]

24. Barbosa, O.; Ortiz, C.; Berenguer-Murcia, Á.; Torres, R.; Rodrigues, R.C.; Fernandez-Lafuente, R. Strategies for the one-step immobilization-purification of enzymes as industrial biocatalysts. Biotechnol. Adv. 2015, 33, 435-456. [CrossRef] [PubMed]

25. Biró, E.; Németh, Á.S.; Sisak, C.; Feczkó, T.; Gyenis, J. Preparation of chitosan particles suitable for enzyme immobilization. J. Biochem. Biophys. Methods 2008, 70, 1240-1246. [CrossRef] [PubMed]

26. Krajewska, B. Application of chitin- and chitosan-based materials for enzyme immobilizations: A review. Enzyme Microb. Technol. 2004, 35, 126-139. [CrossRef]

27. Malmiri, H.J.; Jahanian, M.A.G.; Berenjian, A. Potential applications of chitosan nanoparticles as novel support in enzyme immobilization. Am. J. Biochem. Biotechnol. 2012, 8, 203-219. [CrossRef]

28. Sjoholm, K.H.; Cooney, M.; Minteer, S.D. Effects of degree of deacetylation on enzyme immobilization in hydrophobically modified chitosan. Carbohydr. Polym. 2009, 77, 420-424. [CrossRef]

29. Jesionowski, T.; Zdarta, J.; Krajewska, B. Enzyme immobilization by adsorption: A review. Adsorption 2014, 20, 801-821. [CrossRef]

30. Santos, J.C.S.; Barbosa, O.; Ortiz, C.; Berenguer-Murcia, A.; Rodrigues, R.C.; Fernandez-Lafuente, R. Importance of the support properties for immobilization or purification of enzymes. ChemCatChem 2015, 7, 2413-2432. [CrossRef]

31. Barbosa, O.; Ortiz, C.; Berenguer-Murcia, Á.; Torres, R.; Rodrigues, R.C.; Fernandez-Lafuente, R. Glutaraldehyde in bio-catalysts design: A useful crosslinker and a versatile tool in enzyme immobilization. RSC Adv. 2014, 4, 1583-1600. [CrossRef]

32. Migneault, I.; Dartiguenave, C.; Bertrand, M.J.; Waldron, K.C. Glutaraldehyde: Behavior in aqueous solution, reaction with proteins, and application to enzyme crosslinking. Biotechniques 2004, 37, 790-802. [PubMed]

33. Wine, Y.; Cohen-Hadar, N.; Freeman, A.; Frolow, F. Elucidation of the mechanism and end products of glutaraldehyde crosslinking reaction by X-ray structure analysis. Biotechnol. Bioeng. 2007, 98, 711-718. [CrossRef] [PubMed]

34. Barbosa, O.; Torres, R.; Ortiz, C.; Berenguer-Murcia, Á.; Rodrigues, R.C.; Fernandez-Lafuente, R. Heterofunctional supports in enzyme immobilization: From traditional immobilization protocols to opportunities in tuning enzyme properties. Biomacromolecules 2013, 14, 2433-2462. [CrossRef] [PubMed]

35. Barbosa, O.; Torres, R.; Ortiz, C.; Fernandez-Lafuente, R. Versatility of glutaraldehyde to immobilize lipases: Effect of the immobilization protocol on the properties of lipase B from Candida antarctica. Process Biochem. 2012, 47, 1220-1227. [CrossRef]

36. Betancor, L.; López-Gallego, F.; Hidalgo, A.; Alonso-Morales, N.; Mateo, G.D.-O.C.; Fernández-Lafuente, R.; Guisán, J.M. Different mechanisms of protein immobilization on glutaraldehyde activated supports: Effect of support activation and immobilization conditions. Enzyme Microb. Technol. 2006, 39, 877-882. [CrossRef] 
37. López-Gallego, F.; Betancor, L.; Mateo, C.; Hidalgo, A.; Alonso-Morales, N.; Dellamora-Ortiz, G.; Guisán, J.M.; Fernández-Lafuente, R. Enzyme stabilization by glutaraldehyde crosslinking of adsorbed proteins on aminated supports. J. Biotechnol. 2005, 119, 70-75. [CrossRef] [PubMed]

38. Zaak, H.; Peirce, S.; de Albuquerque, T.; Sassi, M.; Fernandez-Lafuente, R. Exploiting the Versatility of Aminated Supports Activated with Glutaraldehyde to Immobilize $\beta$-galactosidase from Aspergillus oryzae. Catalysts 2017, 7, 250. [CrossRef]

39. Vazquez-Ortega, P.G.; Alcaraz-Fructuoso, M.T.; Rojas-Contreras, J.A.; López-Miranda, J.; Fernandez-Lafuente, R. Stabilization of dimeric $\beta$-glucosidase from Aspergillus niger via glutaraldehyde immobilization under different conditions. Enzyme Microb. Technol. 2018, 110, 38-45. [CrossRef] [PubMed]

40. Peniche, C.; Argüelles-Monal, W.; Peniche, H.; Acosta, N. Chitosan: An Attractive Biocompatible Polymer for Microencapsulation. Macromol. Biosci. 2003, 3, 511-520. [CrossRef]

41. Zhang, Y.; Tao, L.; Li, S.; Wei, Y. Synthesis of Multiresponsive and Dynamic Chitosan-Based Hydrogels for Controlled Release of Bioactive Molecules. Biomacromolecules 2011, 12, 2894-2901. [CrossRef] [PubMed]

42. Betancor, L.; Luckarift, H.R. Bioinspired enzyme encapsulation for biocatalysis. Trends Biotechnol. 2008, 26, 566-572. [CrossRef] [PubMed]

43. Chakraborty, S. Carrageenan for encapsulation and immobilization of flavor, fragrance, probiotics, and enzymes: A review. J. Carbohydr. Chem. 2017, 36, 1-19. [CrossRef]

44. Pierre, A.C. The sol-gel encapsulation of enzymes. Biocatal. Biotransformation 2004, 22, 145-170. [CrossRef]

45. Cao, L.; van Rantwijk, F.; Sheldon, R.A. Cross-Linked Enzyme Aggregates: A Simple and Effective Method for the Immobilization of Penicillin Acylase. Org. Lett. 2000, 2, 1361-1364. [CrossRef] [PubMed]

46. Schoevaart, R.; Wolbers, M.W.; Golubovic, M.; Ottens, M.; Kieboom, A.P.G.; van Rantwijk, F.; van der Wielen, L.A.M.; Sheldon, R.A. Preparation, optimization, and structures of cross-linked enzyme aggregates (CLEAs). Biotechnol. Bioeng. 2004, 87, 754-762. [CrossRef] [PubMed]

47. Sheldon, R.A. Cross-linked enzyme aggregates $\left(\mathrm{CLEA}^{\circledR} \mathrm{s}\right)$ : Stable and recyclable biocatalysts. Biochem. Soc. Trans. 2007, 35, 1583-1587. [CrossRef] [PubMed]

48. Sheldon, R.A. Cross-linked enzyme aggregates as industrial biocatalysts. Org. Process Res. Dev. 2011, 15, 213-223. [CrossRef]

49. Talekar, S.; Joshi, A.; Joshi, G.; Kamat, P.; Haripurkar, R.; Kambale, S. Parameters in preparation and characterization of cross linked enzyme aggregates (CLEAs). RSC Adv. 2013, 3, 12485-12511. [CrossRef]

50. Galvis, M.; Barbosa, O.; Ruiz, M.; Cruz, J.; Ortiz, C.; Torres, R.; Fernandez-Lafuente, R. Chemical amination of lipase $\mathrm{B}$ from Candida antarctica is an efficient solution for the preparation of crosslinked enzyme aggregates. Process Biochem. 2012, 47, 2373-2378. [CrossRef]

51. Rodrigues, R.C.; Barbosa, O.; Ortiz, C.; Berenguer-Murcia, Á.; Torres, R.; Fernandez-Lafuente, R. Amination of enzymes to improve biocatalyst performance: Coupling genetic modification and physicochemical tools. RSC Adv. 2014, 4, 38350-38374. [CrossRef]

52. López-Gallego, F.; Betancor, L.; Hidalgo, A.; Alonso, N.; Fernández-Lafuente, R.; Guisán, J.M. Co-aggregation of Enzymes and Polyethyleneimine: A Simple Method To Prepare Stable and Immobilized Derivatives of Glutaryl Acylase. Biomacromolecules 2005, 6, 1839-1842. [CrossRef] [PubMed]

53. Wilson, L.; Fernández-Lorente, G.; Fernández-Lafuente, R.; Illanes, A.; Guisán, J.M.; Palomo, J.M. CLEAs of lipases and poly-ionic polymers: A simple way of preparing stable biocatalysts with improved properties. Enzyme Microb. Technol. 2006, 39, 750-755. [CrossRef]

54. Ahumada, K.; Urrutia, P.; Illanes, A.; Wilson, L. Production of combi-CLEAs of glycosidases utilized for aroma enhancement in wine. Food Bioprod. Process. 2015, 94, 555-560. [CrossRef]

55. Cruz, J.; Barbosa, O.; Rodrigues, R.C.; Fernandez-Lafuente, R.; Torres, R.; Ortiz, C. Optimized preparation of CALB-CLEAs by response surface methodology: The necessity to employ a feeder to have an effective crosslinking. J. Mol. Catal. B Enzym. 2012, 80,7-14. [CrossRef]

56. Cui, J.D.; Sun, L.M.; Li, L.L. A simple technique of preparing stable CLEAs of Phenylalanine ammonia lyase using co-aggregation with starch and bovine serum albumin. Appl. Biochem. Biotechnol. 2013, 170, 1827-1837. [CrossRef] [PubMed]

57. Dal Magro, L.; Hertz, P.F.; Fernandez-Lafuente, R.; Klein, M.P.; Rodrigues, R.C. Preparation and characterization of a Combi-CLEAs from pectinases and cellulases: A potential biocatalyst for grape juice clarification. RSC Adv. 2016, 6, 27242-27251. [CrossRef] 
58. Mafra, A.C.O.; Kopp, W.; Beltrame, M.B.; Giordano, R.L.C.; Ribeiro, M.P.A.; Tardioli, P.W. Diffusion effects of bovine serum albumin on cross-linked aggregates of catalase. J. Mol. Catal. B Enzym. 2016, 133, 107-116. [CrossRef]

59. Shah, S.; Sharma, A.; Gupta, M.N. Preparation of cross-linked enzyme aggregates by using bovine serum albumin as a proteic feeder. Anal. Biochem. 2006, 351, 207-213. [CrossRef] [PubMed]

60. Torabizadeh, H.; Tavakoli, M.; Safari, M. Immobilization of thermostable $\alpha$-amylase from Bacillus licheniformis by cross-linked enzyme aggregates method using calcium and sodium ions as additives. J. Mol. Catal. B Enzym. 2014, 108, 13-20. [CrossRef]

61. Perkins, E.G. Composition of soybean and soybean products. In Practical Handbook of Soybean Processing and Utilization; Erickson, D.R., Ed.; AOCS Press: St. Louis, France, 1995; ISBN 978-0-935315-63-9.

62. Iwabuchi, S.; Yamauchi, F. Determination of glycinin and $\beta$-conglycinin in soybean proteins by immunological methods. J. Agric. Food Chem. 1987, 35, 200-205. [CrossRef]

63. Thanh, V.H.; Shibasaki, K. Major proteins of soybean seeds. subunit structure of $\beta$-conglycinin. J. Agric. Food Chem. 1978, 26, 692-695. [CrossRef]

64. Utsumi, S.; Inaba, H.; Mori, T. Heterogeneity of soybean glycinin. Phytochemistry 1981, 20, 585-589. [CrossRef]

65. Noda, T.; Furuta, S.; Suda, I. Sweet potato beta-amylase immobilized on chitosan beads and its application in the semi-continuous production of maltose. Carbohydr. Polym. 2001, 44, 189-195. [CrossRef]

66. Vretblad, P.; Axen, R. Preparation and properties of an immobilized Barley $\beta$-amylase. Biotechnol. Bioeng. 1973, 15, 783-794. [CrossRef]

67. Martensson, K.A.J. Preparation of an immobilized two-enzyme system, beta-amylase-Pullulanase, to an acrylic copolymer for the conversion of starch to maltose. I. Preparation and stability of immobilized beta-amylase. Biotechnol. Bioeng. 1974, XVI, 579-591. [CrossRef] [PubMed]

68. Khan, M.J.; Khan, F.H.; Husain, Q. Application of immobilized Ipomoea batata beta amylase in the saccharification of starch. J. Appl. Biol. Sci. 2011, 5, 33-39.

69. Tavano, O.L.; Fernandez-Lafuente, R.; Goulart, A.J.; Monti, R. Optimization of the immobilization of sweet potato amylase using glutaraldehyde-agarose support. Characterization of the immobilized enzyme. Process Biochem. 2013, 48, 1054-1058. [CrossRef]

70. Talekar, S.; Desai, S.; Pillai, M.; Nagavekar, N.; Ambarkar, S.; Surnis, S.; Ladole, M.; Nadar, S.; Mulla, M. Carrier free co-immobilization of glucoamylase and pullulanase as combi-cross linked enzyme aggregates (combi-CLEAs). RSC Adv. 2013, 3, 2265-2271. [CrossRef]

71. Talekar, S.; Ghodake, V.; Ghotage, T.; Rathod, P.; Deshmukh, P.; Nadar, S.; Mulla, M.; Ladole, M. Novel magnetic cross-linked enzyme aggregates (magnetic CLEAs) of alpha amylase. Bioresour. Technol. 2012, 123, 542-547. [CrossRef] [PubMed]

72. Talekar, S.; Waingade, S.; Gaikwad, V.; Patil, S.; Nagavekar, N. Preparation and characterization of cross linked enzyme aggregates (CLEAs) of Bacillus amyloliquefaciens alpha amylase. J. Biochem. Technol. 2012, 3, 349-353.

73. Yoshigi, N.; Okada, Y.; Sahara, H.; Koshino, S. Expression in Escherichia coli of cDNA encoding barley beta-amylase and properties of recombinant beta-amylase. Biosci. Biotechnol. Biochem. 1994, 58, 1080-1086. [CrossRef] [PubMed]

74. Gaouar, O.; Zakhia, N.; Aymard, C.; Rios, G.M. Production of maltose syrup by bioconversion of cassava starch in an ultrafiltration reactor. Ind. Crops Prod. 1998, 7, 159-167. [CrossRef]

75. Shiraishi, F.; Kawakami, K.; Yuasa, A.; Kojima, T.; Kusunoki, K. Kinetic expression for maltose production from soluble starch by simultaneous use of beta-amylase and debranching enzymes. Biotechnol. Bioeng. 1987, 30, 374-380. [CrossRef] [PubMed]

76. Bhattacharya, A.; Pletschke, B.I. Magnetic cross-linked enzyme aggregates (CLEAs): A novel concept towards carrier free immobilization of lignocellulolytic enzymes. Enzyme Microb. Technol. 2014, 61, 17-27. [CrossRef] [PubMed]

77. Kopp, W.; Da Costa, T.P.; Pereira, S.C.; Jafelicci, M.; Giordano, R.C.; Marques, R.F.C.; Araújo-Moreira, F.M.; Giordano, R.L.C. Easily handling penicillin G acylase magnetic cross-linked enzymes aggregates: Catalytic and morphological studies. Process Biochem. 2014, 49, 38-46. [CrossRef]

78. Kumar, V.V.; Sivanesan, S.; Cabana, H. Magnetic cross-linked laccase aggregates-Bioremediation tool for decolorization of distinct classes of recalcitrant dyes. Sci. Total Environ. 2014, 487, 830-839. [CrossRef] [PubMed] 
79. Nadar, S.S.; Rathod, V.K. Magnetic macromolecular cross linked enzyme aggregates (CLEAs) of glucoamylase. Enzyme Microb. Technol. 2016, 83, 78-87. [CrossRef] [PubMed]

80. Park, J.-M.; Kim, M.; Park, J.-Y.; Lee, D.-H.; Lee, K.-H.; Min, J.; Kim, Y.-H. Immobilization of the cross-linked para-nitrobenzyl esterase of Bacillus subtilis aggregates onto magnetic beads. Process Biochem. 2010, 45, 259-263. [CrossRef]

81. Wilson, L.; Illanes, A.; Pessela, B.C.C.; Abian, O.; Fernández-Lafuente, R.; Guisán, J.M. Encapsulation of crosslinked penicillin $\mathrm{G}$ acylase aggregates in lentikats: Evaluation of a novel biocatalyst in organic media. Biotechnol. Bioeng. 2004, 86, 558-562. [CrossRef] [PubMed]

82. Molawa, L.; Jordaan, J.; Limson, J.; Brady, D. Modification of Alcalase SphereZyme ${ }^{\mathrm{TM}}$ by entrapment in LentiKats ${ }^{\circledR}$ to impart improved particle stability. Biocatal. Biotransformation 2013, 31, 71-78. [CrossRef]

83. Cui, J.D.; Li, L.L.; Bian, H.J. Immobilization of Cross-Linked Phenylalanine Ammonia Lyase Aggregates in Microporous Silica Gel. PLoS ONE 2013, 8, e80581. [CrossRef] [PubMed]

84. Jiang, Y.; Wang, Q.; Wang, W.; Zhou, L.; Gao, J. Preparation of immobilized lipase through combination of cross-linked enzyme aggregates and biomimetic silicification. Chin. J. Catal. 2012, 33, 857-862. [CrossRef]

85. Bernfeld, P. Amylases, alpha and beta. In Methods in Enzymology; Colowick, S.P., Kaplan, N.O., Eds.; Academic Press: New York, NY, USA, 1955; pp. 149-158.

86. Miller, G.L. Use of Dinitrosalicylic Acid Reagent for Determination of Reducing Sugar. Anal. Chem. 1959, 31, 426-428. [CrossRef]

87. Vieira, D.C.; Lima, L.N.; Mendes, A.A.; Adriano, W.S.; Giordano, R.C.; Giordano, R.L.C.; Tardioli, P.W. Hydrolysis of lactose in whole milk catalyzed by $\beta$-galactosidase from Kluyveromyces fragilis immobilized on chitosan-based matrix. Biochem. Eng. J. 2013, 81. [CrossRef]

88. Lacerda, L.G.; Almeida, R.R.; Demiate, I.M.; Carvalho Filho, M.A.S.; Vasconcelos, E.C.; Woiciechowski, A.L.; Bannach, G.; Schnitzler, E.; Soccol, C.R. Thermoanalytical and starch content evaluation of cassava bagasse as agro-industrial residue. Brazilian Arch. Biol. Technol. 2009, 52, 143-150. [CrossRef]

89. Gouveia, E.R.; Nascimento, R.T.D.; Souto-Maior, A.M.; Rocha, G.J.D.M. Validation of methodology for the chemical characterization of sugar cane bagasse. Quim. Nova 2009, 32, 1500-1503. [CrossRef]

90. Giordano, R.C.; Giordano, R.L.C. Taylor-Couette vortex flow in enzymatic reactors. In Immobilization of enzymes and cells; Guisan, J.M., Ed.; Humana Press: Totowa, NJ, USA, 2006; pp. 321-332.

91. Bradford, M.M. A rapid and sensitive method for the quantitation of microgram quantities of protein utilizing the principle of protein-dye binding. Anal. Biochem. 1976, 72, 248-254. [CrossRef] 